
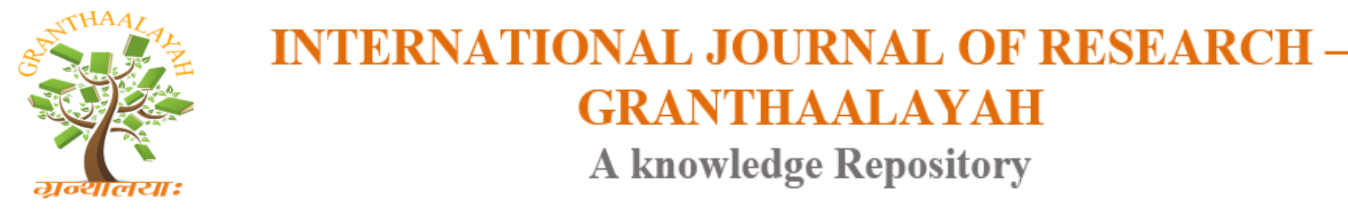

Management

\title{
RISK MANAGEMENT IN MULTI STOREY BUILDING CONSTRUCTION
}

\author{
Radhakrishnan $^{1}$, Dr K G Selvan ${ }^{2}$ \\ ${ }^{1}$ PhD Research Scholar, PRIST University, Thanjavur 613403, India \\ ${ }^{2}$ Associate Dean, PRIST School of Business, PRIST University, Thanjavur 613403, India
}

\begin{abstract}
The Construction Industry is the source for widespread employment for people of all walks of life, next only to Agriculture.

The industry is picking up very well now after the shake of demonetisation. The builders have also understood the importance of RERA and majority of the builders are ensuring total compliance to it.

The GST which was initially looked at as a blow is being viewed in its proper perspective.

The current trend in the construction field is to offer "ready to occupy homes". This is, basically, due to two reasons. Large numbers of builders are in the field doing construction, in almost the entire city and the outskirts.

This healthy competition has necessitated offering maximum benefits to customers and whatever possible to retain them in their fold. In a way, the customers are being attracted so nicely that they have to only pay the initial amount at the time of booking, forget about the bother of EMI, till physical possession.

Since almost all the builders follow the same thing, the customers stand to gain very well.
\end{abstract}

Keywords: Construction Hazards; Fatal Four; M Sand.

Cite This Article: Radhakrishnan, and Dr K G Selvan. (2018). "RISK MANAGEMENT IN MULTI STOREY BUILDING CONSTRUCTION." International Journal of Research Granthaalayah, 6(1), 368-376. https://doi.org/10.29121/granthaalayah.v6.i1.2018.1631.

\section{Introduction}

The boom in the economy results in greater employment opportunities and higher income levels to people. Large scale shift of people from rural areas to urban areas gives rise the need for dwelling places. More number of apartments are needed, with a mixture of ownership and also for rent purposes.

The Government is also concentrating on "House for All" and offering various subsidies and benefits for construction of "dwelling places". 


\section{Research Methodology}

Personal visit to the sites, observation and discussion.

\begin{tabular}{|l|l|}
\hline Contours & Details \\
\hline No. of sites visited & 2 \\
\hline No. of floors & $3 \& 5$ \\
\hline Statutory compliance & $100 \%$ \\
\hline Benefits offered & $\begin{array}{l}\text { Lifts, Covered Car Park, Round the Clock Security, Power Back up, } \\
\text { CCTV Camera }\end{array}$ \\
\hline No. of personnel & $100-150$ (Approx) \\
\hline Female employees & Hardly 10\% \\
\hline Migrated labour & $20 \%$ (approx.) \\
\hline Use of machines & Low in one (3 floors) and Fair in another (5 floors) \\
\hline
\end{tabular}

\section{Higher Rate of Work Injuries in Construction Sites}

It is a fact that construction sector is accident prone. More number of accidents takes place. The rate of fatal accidents is also more. No builder or contractor would like to be exposed in this regard.

In the occurrence of such an untoward incident, they are quick in action for "off the record" settlement. They do not want the bad news to go public. The site being big or small, this is the common feature, as regards fatal accidents are concerned.

The statistics give an alarming picture in this regard.

"About 48,000 workers die in India due to occupational accidents of which 38 fatal accidents take place every day in the construction sector".

In construction industry, majority of accidents take place largely due to negligence on the part of workers and also noncompliance to safety aspects.

In fact, both the sites presented varying scenes.

In one site (the smaller one), people showed scant respect to safety aspects. Most of the activities were done by labourers themselves and use of machines was less. The Site Supervisor was (in local vernacular "Maistry" meaning to say an upgraded Mason) an arrogant person taxing the labourers, with abusive language, often.

The labourers, who were already not safety conscious, were further demoralised by his behaviour. Language problem (for migrated workers) compounded the issue further. Adherence to safety measures at the site was dismally poor.

The maintenance of the site was also not good. The whole site was found to be wet with wastage of water everywhere. The site labourers found it difficult to even walk with load. It is to be noted that a slippery site is deadly to workers. 
The ladders were of bamboo with rope and cloth knots at most of the places. Two workers were holding the ladder at the ground offering physical support, while people were going up with loads. It was understood that only this ladder would be used till completion of the first floor and aluminium ladder was for second and third floors.

The slippers the workers were wearing were covered by cloth pieces.

The Maistry, probably would be under the impression that any accidents taking place up to first floor, could be easily cured by ointments.

The major cause for injuries at the construction sites are broadly brought under these.

It is worth noting the following.

"Construction Hazards - falls from ladders/working platforms/Falls from fragile roofs/fall of materials/collapses of excavation/housekeeping failures/Fire/Electricity/Site vehicles (reversing)/ non wearing of protective Equipments".

\section{Vacant Land Barely As Per Law and No Extra Space Offered}

The land cost being prohibitive, especially, in the city, all the builders give only the minimum space that is prescribed by statutory authorities. They do not want to incur wasteful expenses for offering even an inch more than the statutory requirements.

From the point of view of post possession, space management would be a difficult proposition for the inmates, as invariably, each family has one car and two to three two wheelers.

Even during construction itself, with loaded materials, bricks and sand and a host of other construction items, the operating space for construction is heavily hindered. This is keenly felt during concrete laying.

The workers get easily fatigued. They find it extremely difficult to even walk. Walking becomes tiresome with load on head. This is so acute, especially when the construction is taking place between two already built up structures.

In the space constraint, machines make impact accidents with adjacent buildings.

Technically, the hazardous materials are to be safely kept with appropriate warning to operating staff about the same. Whereas, this was not followed in the smaller site.

The author was given a private remark that one of the workers fell down with load on his head, while climbing up, from the ladder. The bamboo ladder was tied with cloth and rope which gave way even for a small weight.

As the fall was from on the way to first floor, it was over with injuries to the helper. Whereas, if it was from second or third floor, it would have led to fatality. 
Electricity connections were also found loosely hanging everywhere. The whole area being wet due to poor housekeeping, chances of electrocution were more.

The workers were working in a totally unhappy and unsafe condition.

The most common causes attributable to work injuries at the site can be succinctly expressed as under.

"Overexertion/Impact Accidents/Falls/Bodily Reaction (to chemicals, fire, electricity etc.)/Compression"

Effective Strategies for preventing slips and falls are:

Ramps and sloped floors have high friction surfaces/Stairs must have handrails/Safety Mats/Nonslip flooring/Slip resistant surface shoes.

Hazardous areas should be fully lighted"

\section{Mitigate Risks}

Construction sites are known for their danger. Extreme care should be shown by all the people working at the site. A slip while walking on the ground may cause injuries and whereas the same from the floors would be disastrous.

Goes without saying that when the floors are more, care and caution should also be more as the risk factor is also growing up alongside.

A prudent Site Engineer should show more attention in proper upkeep of the site. Basically, the construction site should be clean - however big the project is and whatever be the level of hectic activities. In other words, what this precisely means is that "there should be a place for everything and everything should be in its place". This is the basic instruction for TQM and this essentially is required at the construction sites.

There are occasions when the cranes find it difficult to place the pre-stressed concrete bars owing to space constraint and more difficult is lifting the same from where it was staked.

Logistics Management is not just confined to trucks but overall space management. Space management at the site is the more crucial one.

Handling workers at the site is as difficult as space management. The construction workers being mostly illiterate need closer observation and more in depth training in the work activities.

The following must be adhered to, in all earnestness at the site.

- Walking ways should be free from hazards.

- In each floor, First Aid Box complete with Medicines must be there.

- Hazardous materials should be properly labelled, kept separately and fully lighted. 
- Workers should be trained on handling of hazardous materials and how to protect themselves in the event of a risk.

- Each floor must have Fire Extinguishers and each one must be periodically certified for fitness.

- Materials must be properly staked to avoid toppling.

- Aluminium ladders should be used.

- Gas cylinders to be kept safely.

The Site Engineer must have a chart clearly depicting the possibility of unsafe occurrence and the preventive measures for same.

It should be a three column chart.

\section{\begin{tabular}{|l|l|l|}
\hline Activity & Possibility of unsafe occurrence & Preventive measures \\
\hline
\end{tabular}}

This would enable him identify the risks and avert the same.

\subsection{Beware of the Fatal Four and Get Protected from Same}

Construction sites are known for their danger. Nevertheless, we have to work on there, with care and caution.

The Fatal Fours are (i) Falls (ii)Electrocution (iii) Struck by Object and (iv) Caught in between.

\section{Falls}

Falls are a leading cause of fatalities and serious injuries. Majority of the sites do not have proper fall protection.

- Provide a guard rail and toe-board around every elevated open sided platform, floor and runway, as well as around dangerous machines and equipment.

- Provide employees with Personal Protective Equipment and impart training to them on operation of same, in their own vernacular, for perfect understanding.

\section{Electrocution}

It is said that electrical hazards cause more than 300 deaths and 4,000 injuries in the workplace each year. Electricity is a serious workplace hazard and with proper precautions, the fatalities can be easily avoided.

- Impart safety training and proper Personal Protective Equipments (PPEs) to employees. This must be insisted upon, in their own interest.

\section{Struck by Object}

This could be due to falling (suspended load coming loose), flying (thrown tools or debris), swinging (load swaying) or rolling (vehicle or heavy equipment in motion). 
Normally, the workers are caught unawares and get struck. To arrest these:

- Wear safety glasses, goggles or a face shield and always wear Personal Protective Equipments (PPEs).

- Secure Tools and Materials using toe boards, screens and debris nets.

- Always wear hard hat at the site.

- Never go near or under a suspended load. When working in conjunction with heavy equipments, be always under the clear vision of the operator.

\section{Caught - in - Between}

These are accidents where a worker's body part is caught, crushed or squeezed between two or more objects and happen as a result of collapsing materials, body pulled into unguarded machinery and equipment rollovers. How to avoid?

- Be Absolutely Familiar with the Equipments

- Shut down the equipment before doing any repair

Continuous training programmes to all the working staff at the site, is a Must. Even if they know all these, a periodic Refresher is a Must so that they always remember, by default, at the work site and be Wary.

\section{How To Ensure Risk Management At Work Site}

The other site (5 floors) had, remarkably, all the safety features and practices.

The Builder, who himself is a Civil Engineer, positioned two Site Engineers at the site monitoring the Supervisors and Site In Charge.

The Site Engineers are multi lingual persons and hence have no difficulty in handling migrated workers.

Both the Site In Charge and Supervisor were always under the close supervision of the Site Engineers. This instilled a feeling of discipline in their minds in doing their own work and also guiding the work force.

Though this site also had only essential open space as prescribed by law, the space management at the site was superb.

Debris was kept at the farthest end of the site. Periodic removal was also done for hassle free operation of the site personnel.

All the site personnel compulsorily wear hard hat.

Sign Boards and Caution Boards were kept at all required places.

Logistics Management was excellent which contributed to space management and free movement of men and materials. 
For people doing risky job, Personal Protective Equipments were to be compulsorily worn. Those who turn up to the site without these were not allowed entry into the site. This was strictly followed.

Continuous work training was conducted to all site personnel.

All safety devices were present and procedures meticulously followed.

Excellent Supply Chain Management system was in practice. No pile up of materials or starvation of work for materials. A sort of military discipline was observed.

The attitude of human beings is that when systems and procedures are meticulously followed, even lethargic people will automatically fall in line with the rigour of the system and become disciplined.

Work was going on smoothly and no gossip or whiling away the time was noticed. All the personnel were fully aware of their role and doing the job as per work instructions prescribed to them. Workers had free access with Site Engineer for any emergency advice. The Site Engineer was particular in getting feedback from the site personnel on the instructions passed on to them and also the work done by them.

This, not only led to closer inter action with all the people at the site but also a congenial work culture enhancing the overall productivity.

Cranes, Trucks and other vehicles come at the right time and leave the site immediately as soon as the job is through. The time and space of the site was not wasted.

A clean atmosphere will enthuse the morale of the workers. This was evidently proved at the site. In this context, it is worthwhile noting the following.

"Managing people and performance is a discipline and skill which requires a careful, integrated approach to managing all issues and aspects - from communications to behavioural consequences, from feedback to trust".

\section{Conclusion}

The most important thing is not to change the structural design or make any deviation from the original plan. This will not only destabilise the construction but will also lead to even collapse of the building, sooner or later. Globally also, this sort of mistakes are common occurrence.

Repetitive jobs will weaken the structure. A job once completed should not be worked again, unless otherwise absolutely essential.

Never make additional flooring than what is originally planned for. The main reason is that the structural design of the building has been done only in such a way and further loading will cause shaking the structure to the root. 
Never compromise on the quality of pipes. Poor quality pipes will lead to leakage and unnoticed leakages will cause seepage in the wall and spread over the entire structure. This is a silent submerge of the apartment.

Electrical items should also be of high quality.

Even established builders suffered bad name with their customers due to pipe and electrical issues.

\section{Recommendations}

Always strict to Quality of the products being used in construction. Never use different brands of materials. Uniformity is recommended not only from the point of view of easy procurement and other things, but mainly from the point of view of uniform quality as well.

Cement and Steel should be of same quality and same brand throughout the construction.

While M Sand is now widely recommended as a substitute for River Sand, uniformity of the sand is a Must. Never attempt to have mixture of both M sand and R sand for the work.

Human Resources is precious. Use the same labour force till completion. This will help in accelerating the execution. Frequently, changed workers will give lesser productivity and the work will also end up in mess.

As movements and activities are so much in the site, orderliness and cleanliness is a must for risk free operation.

Gas Cylinders, Combustible items and hazardous materials should always be kept separately duly fenced and lighted.

Pay extra attention on electrical items. In large constructions, electrical fires are a common incident. Extinguishing electrical fire is also a cumbersome and risky process.

Last but not the least, never rush through the process for early completion. Accumulated risks will assault the construction.

\section{References}

[1] http://indianexpress.com/article/india/accidents-at-workplaces-in-india-under-reported-38-perday-in-construction-sector-study-4947079/

[2] Pages 274, 275, 285 \& 286. Book name: Health \& Safety at Work - Revised eighth edition. Author: Jeremy Stranks, Copy right @ Jeremy Stranks, First Indian Edition 2010. Published by: Kongan Page India Private Limited, 4737/23, Ansari Road, Daryaganj, New Delhi 110002. ISBN: $978-81-7554-547-2$.

[3] Pages 26, 27, 411 and 414. Book Name: Occupational Safety and Health for Technologists, Engineers and Managers - Sixth Edition. Author: David L Goetsch, Copy right 2008, 2005, 2002, 1999, 1996 and 1993 by Pearson Education Inc, Upper Saddle River, New Jersey 07458. 
Published by Pearson Prentice House, Upper Saddle River, New Jersey, and Columbus, Ohio. ISBN: 13: $978-0-13-239760-5$ and ISBN: 10: $0-13-239760-9$.

[4] Pages 52 - 54. Book Name: Safety, Health and Asset Protection - Management Essentials Second Edition. Edited by Richard W Lack. Published by Taylor \& Francis, copy right @ 2002, by CRC Press. CRC Press, 2000, N W Corporate Blvd, Boca Raton, Florida 33431. ISBN: 1 $56670-370-0$.

[5] http://www.arbill.com/arbill-safety-blog/top-4-causes-of-construction-deaths-steps-to-preventthese-tragedies

[6] Pages 161 - 162. Book Name: Management by Process - A Roadmap to Sustainable Business Process Management. Authors: John Jeston and Johan Nelis. Copyright @ 2008 John Jeston and Johan Nelis. First edition 2008, published by: Butterworth-Heinemann is an imprint of Elsevier, Linacre House, Jordan Hill, Oxford OX2 8DP, UK, and 30, Corporate Drive, Suite 400, and Burlington, MA 01803, USA. ISBN: 13: $978-0-7506-8761-4$.

*Corresponding author.

E-mail address: srk1960@yahoo.in/drcsrv@ gmail.com 